\title{
Cuerpos de agua, de Silvia Barei
}

Alción, Córdoba, Argentina, 2004

Reseña: Pampa Arán

Universidad Nacional de Córdoba

"Memoria ingrávida"

Sentir como quien mira. Pensar como quien anda,

y cuando se ha de morir,

recordar que el día muere y que el poniente

es bello y es bella la noche que queda.

Así es y así sea.

F. Pessoa, Odas

Cuerpos de agua es el último libro de poemas de la escritora cordobesa Silvia Barei (2004; en Alción edit. ha publicado también Que no quiebre el conjuro la palabra, 1992 y De humana condición, 1997). El nuevo libro se compone de minúsculas escenas, instantes, instantáneas, atravesadas por la fulguración de la memoria en permanente pasaje hacia la desmaterialización. Siempre en suspenso, suspendida, la materialidad del mundo, la del cuerpo (y la del sentido) se disuelve y recompone para hablar de las metamorfosis de los sueños, de las pasiones, del dolor y de las ciegas voces que lo habitan, ya que ésa "Es su manera de estar en el mundo" (p. 67).

El oxímoron anunciado por el título sintetiza la pregnante figura de la disolución (y desolación) que recorre toda la obra: cuerpo náufrago, flujo incesante, pasaje a lo líquido, al vasto mar sin orillas, sin puerto seguro, existencia en el límite de lo decible. Así, las tres partes en que se organiza el poemario van cambiando el ritmo y el tono, sufriendo mutaciones finamente trabajadas que emergen a medida que uno las circunda buscando en vano un centro, siempre en irremediable fuga de sí mismo, porque no hay lugar de donde provenga la luz, ni punto exacto para algún observador.

En la primera parte -Cuerpos- la pregunta insistente es por la vida, por los cuerpos anudados que resisten, por la incomodidad de la razón, al borde de la locura, la terca enseñanza del amor y del cuerpo amado que se desea, la torpe retórica de la máscara y del dolor que acechan en lo real. Lo inteligible y lo sensible, el yo y los otros, luz y sombra, colocan al sujeto en el meridiano vital de una existencia femenina que conoce : “(...) la escisión entre la historia de sí misma / y las políticas de los otros / los lugares de la mujer / y los lugares / deseados en lo íntimo / -yo aquí, excéntrica y con vos- / el rechazo, la exasperación y el miedo" (pp. 15-16).

Existir no es plenitud; es falta, ausencia, carga silente, deudas con el pasado. ¿Quién dice la palabra salvífica? ¿Quién habla por su boca o escribe por su mano? En el juego de espejos se multiplican los nombres y las voces que de un modo misterioso se albergan en las vidas de otras vidas, rostros opacos que repiten las variaciones de un destino "Pero alguien dicta el poema" (p.18).

Por eso, la experiencia del momento primigenio y saludable del amor humano, 
de la amistad, de la corpórea densidad del abrazo como una fiesta de la vida, es apenas un destello de ingrávida memoria, un cielo fugitivo, una niebla creciente "Otra vez el cielo que huye / y convierte el suelo en escarcha" (p. 31).

Si la primera parte parece capturar la fragilidad del instante tensivo de la vida que se imaginó o se pudo vivir, la foto, el instante, el poema, la porfía de sustraer vida de la muerte, la segunda parte - de agua - delinea una geografía fracturada en la que cada lugar, el realmente habitado y conocido, el posible y el del recuerdo, Lanzarote, Lisboa, Venecia, Varsovia, Córdoba, Tenochtitlán, repiten y amplifican un paisaje lunar que la escritura registra con ansiedad teñida de muerte: "En vez de su cuerpo / esta escritura / palabra inclinada hacia la ausencia / virtual, frágil, fractal, / fría, alucinada / y mortal.” Si se pudiera elegir el lugar para morir, sería el lugar casi mítico del origen, en la conjunción de los tiempos, sería en el río de la infancia, sería en el mar, en el origen de la vida, sería en la zona líquida de la impermanencia, en la sombra que cruza el agua que anda inquieta y oscura. Lugares de agua los de la memoria, vida fluvial que traza un curso que apenas deja huella o sentido en la huella y que en la "Inminencia de diluvio" busca todavía tercamente la voz extraviada en el oleaje de lo humano.

Pero la trama de la muerte se teje con varios hilos, siempre entre dos orillas, funde y confunde los relatos, los lugares, los pronombres, la muerte propia, la muerte ajena. Y la escritura rescata del ubi sunt, sigilosamente, en un epígrafe de Edgar Bayley, las muertes colectivas que mece el gran río: "Puede el mundo tu país tu propia mano / cambiarse al fin / cambiarse en agua en lechos en mis hermanos" (p. 35) y que enlaza con los primeros poemas de inspiración pessoana, escenario de guerra, muerte y tortura.

La Esfera Pessoa compone la tercera y última parte del poemario y abre un diálogo con la escritura, el lenguaje que reescribe al otro, ficcionaliza o cita, interpreta y responde. Calar el propio verso inter-calando el ¿ajeno?, hacerle lugar al otro y ser el otro, perder la identidad en los heterónimos, con-fluyendo y desandando, también como un río, el surco de las palabras. El otro interpela "Me hace preguntas / como si toda voz no fuera / palabra repartida. / O resguardo de la memoria. / O roces de rostros apenas conocidos" (p. 71). En ese "blanco espacio de revelaciones" (p. 79) parece posible un resguardo provisorio de la muerte acechante, de la realidad indiferente, del animal oficio humano. Espacio de la espera, sin esperanza, lugar de la belleza entrevista, sitio de la mirada que cree ver y también lugar íntimo y recóndito en el que se puede resistir la realidad del mundo que no nos necesita, pero apremia.

Como señala con agudeza Elena Bossi en la contratapa del libro, la poesía de Barei "lleva la mirada lúcida hacia la condición humana y la cubre de piedad". Nosotros añadiremos que como una Piedad trágica, compone el rictus del propio cuerpo y del otro cuerpo, amorosamente sostenido en el dolor de la existencia sin promesa. Porque si nada, ni el nombre, ni siquiera la palabra permanece para siempre, solo queda la ingrávida memoria, el agua y el viento. 